\section{Boosting adjuvants}

\section{By Stephen Parmley, Senior Writer}

For all the talk of new vaccines, not much attention has been paid to the need for better adjuvants, which have remained stuck on alum-based products for decades. The NIH is committing up to $\$ 70$ million over the next 5 years to new adjuvant research and wants to prod industry to pick up the mantle and develop a diverse portfolio of agents. But it will need to persuade companies that in the long run, pooling their knowledge will be commercially worthwhile.

The NIH's goal is to have a toolbox of adjuvants that can boost vaccine efficacy, increase response rates in the elderly and extend the supply of critical vaccines for public health. Adjuvants increase the magnitude and duration of vaccine-induced protective immunity by stimulating aspects of the immune system - such as the innate response-that have evolved to respond to infections.

Historically, companies have lacked an incentive to develop adjuvants as products in and of themselves because the returns were so poor. Instead, they have generally developed antigens and adjuvants together within specific vaccine programs.

Novartis AG spokesperson Elizabeth Power told SciBX, "At Novartis, we do not develop adjuvants separately from antigens but rather consider the precise combination of the proper antigens and adjuvant targeting a specific disease. Then, the value of the vaccine can be demonstrated through overall safety and efficacy."

In other cases, when companies do develop proprietary adjuvants, they tend to retain them within their internal programs and rarely license them out.

The NIH is trying to bring pharma back to the table in adjuvant discovery because of the huge unmet need for vaccines in developingworld diseases. One argument put forward is that more effective adjuvants could make vaccines for developed markets more profitable as they would lower the dose of antigen needed to induce immunity and make the vaccine cheaper to produce in large amounts.

Wolfgang Leitner told SciBX, "We want a pipeline of novel adjuvants, and we want adjuvants that give you dose sparing and that improve efficacy of the vaccine but without increasing the toxicity or adverse events." Leitner is a program officer at the NIH's National Institute of Allergy and Infectious Diseases (NIAID) and is the contracting officer's representative for adjuvant discovery contracts.

The NIH is awarding the money to researchers for seven projects at two companies-Vaxine Pty. Ltd. and GlaxoSmithKline plcand five universities or hospitals (see Table 1, "Adjuvant discovery contracts").

The funding represents the third tranche from the institute for adjuvant development since 2003. It is also part of a strategy to increase

vaccine efficacy, particularly in vulnerable subpopulations in which vaccine-based immunization is needed most.

In 2004, the NIH awarded close to $\$ 50$ million to 1 university and 4 companies-including Corixa Corp., now part of GSK. In 2008, the NIH awarded contracts totaling over $\$ 57$ million to 5 academic institutions and GSK.

Whereas the first two funding rounds focused on compounds that broadly stimulate innate immune responses by agonizing toll-like receptors (TLRs) and other innate receptors, the new awards center on identifying targeted compounds that stimulate specific cells in the innate and adaptive systems such as dendritic cells (DCs), mast cells, NK T cells and $\gamma \delta$ T cells.

"The traditional model
has been to develop an
adjuvant and use it for
everything in your portfolio,
but we are finding now
that each one has its own
useful indication, but
it does not work for all
indications."
-Jay Evans, GlaxoSmithKline plc

Jay Nelson told SciBX that it is widely acknowledged that better adjuvants could make a difference in populations such as the very young and very old who often respond poorly to vaccines. Nelson is one of the new award recipients and a senior molecular virologist at Oregon Health \& Science University.

"If you look at immunocompetent adults immunized for flu, 80\%$90 \%$ will respond with protective immunity, but if you look at adults over 65 , that number drops to $20 \%-40 \%$," he said.

In addition to better immune boosting, improvements in adjuvants could reduce the amount of vaccine antigen needed and the number of vaccinations to achieve immunity-which could in turn extend the supply of vaccines.

\section{Tailor's toolbox}

As knowledge about the immune response to infections has grown, vaccine development has moved toward triggering specific mediators of protective immunity such as B cells, NK T cells, mast cells or T helper type 1 (Th1) and Th2 cells-but adjuvant development has not kept pace.

Apart from alum there are only three adjuvants approved in the U.S. and Europe-GSK's AS03 and AS04 and Novartis' MF59-and one in registration-GSK's AS01-all of which stimulate broad immune responses.

Alum, which is composed of aluminum salts, was first used as an adjuvant in vaccines 70 years ago and is now part of many vaccines against infectious diseases including HBV infection and pneumococcal diseases. At least 19 other adjuvants are in development, but many are agonists of the innate system and are also likely to stimulate broad immune responses (see Table 2, "Selected adjuvants and adjuvanted vaccines for infectious disease").

"Earlier vaccine research was focused on the strength of the immune response-how much antibody or cytokine do you get-and what was often overlooked was the quality of the immune response," said Leitner. Adjuvants were added to boost the response, he noted, but because they induce broad immune responses, they also increase the risk of side effects. 
Table 1. Adjuvant discovery contracts. The NIH has awarded contracts totaling more than $\$ 70$ million for 7 new adjuvant discovery projects. Amounts shown represent the potential contract value if all options are exercised.

Source: NIH

\begin{tabular}{|c|c|c|c|}
\hline $\begin{array}{l}\text { Principal } \\
\text { investigator }\end{array}$ & Institution & Project summary & $\begin{array}{l}\text { Potential value } \\
\text { (\$M) }\end{array}$ \\
\hline Jay Evans & $\begin{array}{l}\text { GlaxoSmithKline plc (LSE:GSK; } \\
\text { NYSE:GSK) }\end{array}$ & $\begin{array}{l}\text { Synthesize and screen libraries of molecules that could function as adjuvants for } \\
\text { a tuberculosis vaccine }\end{array}$ & 13.4 \\
\hline Sunil David & The University of Kansas & $\begin{array}{l}\text { Screen small molecule libraries for agonists of toll-like receptor } 2 \text { (TLR2), TLR5, } \\
\text { TLR7, TLR9, caspase recruitment domain family member } 4 \text { (CARD4; NOD1) } \\
\text { and CARD15 (NOD2) that could act as adjuvants }\end{array}$ & 10.3 \\
\hline Jay Nelson & Oregon Health \& Science University & $\begin{array}{l}\text { Screen small molecule libraries for agonists of interferon regulatory } \\
\text { transcription factors as vaccine adjuvants }\end{array}$ & 10 \\
\hline Dennis Carson & University of California, San Diego & $\begin{array}{l}\text { Screen small molecule libraries for compounds that inhibit the negative } \\
\text { feedback signals in antigen-presenting cells and prolong their activation }\end{array}$ & 9.8 \\
\hline Nikolai Petrovsky & Vaxine Pty. Ltd. & $\begin{array}{l}\text { Screen libraries of natural compounds that activate dendritic cells and run high- } \\
\text { throughput computational screens to identify compounds that activate NK } \\
\text { T cells or stimulate TLR9 }\end{array}$ & 9.7 \\
\hline Ofer Levy & Boston Children's Hospital & $\begin{array}{l}\text { Screen small molecule libraries to identify potential adjuvants for use in adults, } \\
\text { newborns or the elderly }\end{array}$ & 9.4 \\
\hline Herman Staats & Duke University & Screen small molecule libraries for stimulators of mast cells as adjuvants & 8.4 \\
\hline
\end{tabular}

Leitner told SciBX that the NIH wants new adjuvants that can reduce those risks by triggering specific immune responses associated with individual vaccines. "Ideally you are picking a couple different adjuvants to test with your vaccines," he said. "By having that toolbox of adjuvants with very defined mechanisms of action and defined immune profiles, it will be much easier to find the right combination for different types of vaccines."

According to Leitner, industry activity has been sluggish in the field in part because of regulatory concerns about adjuvant safety. "Rino Rappuoli wrote in one of his articles" that the development of vaccine adjuvants may be one of the slowest processes in the history of medicine," he said. "I couldn't agree more."

Rappuoli is global head of R\&D at Novartis Vaccines.

Leitner added that when pharma does pursue adjuvant discovery it is primarily in the context of a specific vaccine product and does not necessarily yield adjuvants that can be used with other vaccines. "Pharmas are also limited in what they can combine because they need IP on the components. So, for example, GSK is only combining the compounds that they own."

Jay Evans, senior scientist and investigator at GSK, told SciBX that from industry's perspective, adjuvant discovery and development is time consuming, challenging and costly. Evans is one of the recipients of the NIAID awards.

He added that the best way to make progress in the field is to develop a suite of agents that would give a company versatility for its internal programs. "The traditional model has been to develop an adjuvant and use it for everything in your portfolio, but we are finding now that each one has its own useful indication, but it does not work for all indications," he said. "We are finding that the toolbox might have some gaps in it, especially for some of the harder-to-treat diseases which adjuvants are being used for now."

\section{Filling in the gaps}

Because little is known about how alum acts as an adjuvant, a second major goal of the NIH program is to better understand the mechanisms of action of new adjuvants that are discovered.
"If you think about alum, it has been around for a hundred years and we still have no clue how it works," said Leitner. "We will have researchers looking at why alum does what it does, how it does it, and that will keep them busy for a while."

In the NIAID-funded projects' first few years, the research teams will screen a combined total of more than one million compounds to find agents capable of stimulating human immune cells involved in both the innate and adaptive responses. Unlike many previous screening efforts, the primary screens will include

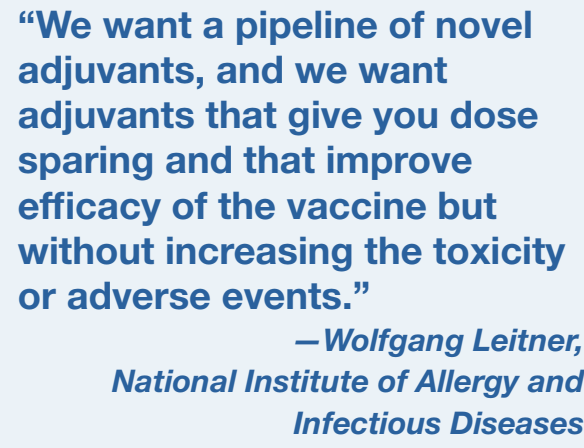
adjuvants, and we want adjuvants that give you dose sparing and that improve efficacy of the vaccine but without increasing the toxicity or adverse events."

-Wolfgang Leitner,

National Institute of Allergy and Infectious Diseases assays to eliminate compounds likely to have safety issues.

Herman Staats, an award recipient and a professor of pathology at Duke University, told SciBX that his team will be looking for a new class of adjuvant that directly stimulates mast cells. "Mast cells upon activation release several key immune regulatory mediators that activate dendritic cells and $\mathrm{T}$ cells, resulting in powerful adaptive immune responses," he said.

Nelson's team at the Oregon Health \& Science University plans to screen at least 100,000 compounds that directly stimulate human dendritic cells-a key player in adaptive immunity -and use primary screens to eliminate compounds that are cytotoxic, cause nonspecific activation, directly stimulate $T$ and $B$ cell activation or induce inflammatory cytokines. Nelson told SciBX that these more rigorous filters will help the researchers identify compounds tailored to stimulate specific immune pathways that have a lower risk of safety problems.

Evans said that the GSK team will screen for classes of adjuvants that are new to GSK and could fill a potential gap in the company's pipeline of adjuvants. He said that the team would assess both the mechanism and potential side effects early in the screening process to optimize the design of safe adjuvants with tailored responses.

Parmley, S. SciBX 7(44); doi:10.1038/scibx.2014.1281

Published online Nov. 13, 2014 
Table 2. Selected adjuvants and adjuvanted vaccines for infectious disease. Although many marketed vaccines for infectious diseases use alum as an adjuvant, there are three marketed vaccines and one in registration that use newer adjuvants. In addition, there are at least 17 new adjuvants being paired with protective vaccines in various stages of development. At least two other preclinical adjuvant candidates are not yet paired with a vaccine.

Source: BCIQ: BioCentury Online Intelligence

\begin{tabular}{|c|c|c|c|c|}
\hline Adjuvant & Adjuvant description & $\begin{array}{l}\text { Corresponding } \\
\text { vaccine }\end{array}$ & Company & Status \\
\hline AS03 & $\begin{array}{l}\text { Oil-in-water emulsion with } \\
\text { squalene, DL- } \alpha \text {-tocopherol and } \\
\text { polysorbate } 80\end{array}$ & $\begin{array}{l}\text { Q-Pan, an H5N1 influenza } \\
\text { vaccine }\end{array}$ & GlaxoSmithKline plc (LSE:GSK; NYSE:GSK) & Marketed \\
\hline AS04 & $\begin{array}{l}\text { Alum and monophosphoryl lipid A } \\
\text { (MPL), a toll-like receptor } 4 \\
\text { (TLR4) ligand }\end{array}$ & Cervarix, an HPV vaccine & GSK & Marketed \\
\hline MF59 & $\begin{array}{l}\text { Oil-in-water emulsion with } \\
\text { squalene }\end{array}$ & Fluad, an influenza vaccine & Novartis AG (NYSE:NVS; SIX:NOVN) & Marketed \\
\hline AS01 & $\begin{array}{l}\text { GSK's MPL and Agenus Inc.'s } \\
\text { (NASDAQ:AGEN) QS- } 21 \\
\text { Stimulon, a purified saponin } \\
\text { adjuvant }\end{array}$ & Mosquirix, a malaria vaccine & GSK; Agenus & Registration \\
\hline $\begin{array}{l}\text { Immunostimulatory } \\
\text { DNA sequences }\end{array}$ & TLR9 ligand & Heplisav, an HBV vaccine & Dynavax Technologies Corp. (NASDAQ:DVAX) & Phase III \\
\hline IC31 & $\begin{array}{l}\text { Leucine-rich peptide KLK and } \\
\text { synthetic oligonucleotide ODN1a }\end{array}$ & $\begin{array}{l}\text { AERAS- } 456 \text {, a Mycobacterium } \\
\text { tuberculosis (TB) vaccine }\end{array}$ & $\begin{array}{l}\text { Aeras; Statens Serum Institute; Valneva SE } \\
\text { (Euronext:VLA; VSE:VLA) }\end{array}$ & Phase II \\
\hline IL-2 protein & Vector-encoded $I L$-2 gene & TG4001, an HPV vaccine & $\begin{array}{l}\text { Transgene S.A. (Euronext:TNG); European } \\
\text { Organization for Research and Treatment of Cancer }\end{array}$ & Phase II \\
\hline Endocine & Endogenous human lipids & $\begin{array}{l}\text { Immunose FLU, an influenza } \\
\text { vaccine }\end{array}$ & Eurocine Vaccines AB (AktieTorget:EUCI) & Phase I/II \\
\hline $\begin{array}{l}\text { Bacterium-like particles } \\
\text { (BLPs) }\end{array}$ & Self-adjuvanting vehicles & FluGEM, an influenza vaccine & Mucosis B.V. & Phase I/II \\
\hline Matrix M & Saponin-derived purified product & Influenza vaccine & $\begin{array}{l}\text { Novavax Inc. (NASDAQ:NVAX); Johnson \& Johnson } \\
\text { (NYSE:JNJ) }\end{array}$ & Phase I/II \\
\hline Flagellin & TLR5 ligand & VAX102, an influenza vaccine & VaxInnate Corp. & Phase I/II \\
\hline ABX196 & Undisclosed & ABX196, an HBV vaccine & Abivax S.A.S. & Phase I \\
\hline $\begin{array}{l}\text { Glucopyranosyl lipid A } \\
\text { (GLA) }\end{array}$ & TLR4 ligand & $\begin{array}{l}\text { MEDI7510, a respiratory } \\
\text { syncytial virus (RSV) vaccine }\end{array}$ & $\begin{array}{l}\text { AstraZeneca plc (LSE:AZN; NYSE:AZN); Immune } \\
\text { Design Corp. (NASDAQ:IMDZ) }\end{array}$ & Phase I \\
\hline $\begin{array}{l}\text { Granulocyte } \\
\text { macrophage colony- } \\
\text { stimulating factor (GM- } \\
\text { CSF; CSF2) protein }\end{array}$ & Vector-encoded GM-CSF gene & GOVX-B21, an HIV vaccine & GeoVax Labs Inc. (OTCBB:GOVX) & Phase I \\
\hline $\begin{array}{l}\text { GLA-stable emulsion } \\
\text { (GLA-SE) }\end{array}$ & TLR4 ligand & TB vaccine & Infectious Disease Research Institute; Aeras & Phase I \\
\hline W805EC & Oil-in-water emulsion & NB-1008, an influenza vaccine & NanoBio Corp.; Merck \& Co. Inc. (NYSE:MRK) & Phase I \\
\hline $\begin{array}{l}\text { Immunostimulatory } \\
\text { double-strand RNA } \\
\text { sequences }\end{array}$ & TLR3 ligand & ND1.1, an influenza vaccine & Vaxart Inc. & Phase I \\
\hline Advax & Inulin-derived product & HBV vaccine & Vaxine Pty. Ltd. & Phase I \\
\hline Vaxfectin & Cationic lipid-based formulation & Dengue virus vaccine & Vical Inc. (NASDAQ:VICL) & Phase I \\
\hline Adjuplex & $\begin{array}{l}\text { Lecithin and carbomer } \\
\text { homopolymer }\end{array}$ & Not applicable & Advanced BioAdjuvants LLC & Preclinical \\
\hline AT-1004 & Zonulin receptor peptide agonist & Not applicable & Alba Therapeutics Corp. & Preclinical \\
\hline MAS-1 & $\begin{array}{l}\text { Oil-and-water nanoparticle } \\
\text { emulsion }\end{array}$ & $\begin{array}{l}\text { MER4101, an influenza } \\
\text { vaccine }\end{array}$ & Mercia Pharma Inc. & Preclinical \\
\hline P3CSK4 & TLR2 lipopeptide ligand & RSV vaccine & Mymetics Corp. (OTCBB:MYMX) & Preclinical \\
\hline
\end{tabular}

\section{REFERENCES}

1. De Gregorio, E. et al. Eur. J. Immunol. 38, 2068-2071 (2008)

COMPANIES AND INSTITUTIONS MENTIONED

Duke University, Durham, N.C.

GlaxoSmithKline plc (LSE:GSK; NYSE:GSK), London, U.K.
National Institute of Allergy and Infectious Diseases, Bethesda, Md

National Institutes of Health, Bethesda, Md.

Novartis AG (NYSE:NVS; SIX:NOVN), Basel, Switzerland

Oregon Health \& Science University, Beaverton, Ore.

Vaxine Pty. Ltd., Garran, Australian Capital Territory, Australia 